\title{
Measuring the Influence of Environmental Policy on Economic Development of the Countries: EU-28 Scope
}

\author{
Marta VOVK* - Viktoriia VARENYK**_Zoia PESTOVSKA**_ \\ Petro ATAMAS**_Oleksandr ATAMAS***_Valentyna SHEVCHENKO****
}

\begin{abstract}
In current paper, we have researched the influence of environmental policy stringency (EPS) on economic development of the EU-28. The problem of identifying the influence of stringency of environmental policy $(E P)$ on economic development of the EU-28 is that currently there is no well-established understanding of what economic results can be achieved depending on the extent of EPS within a separate country. The paper aims at making contribution to theoretical, empirical and political scopes of perception of EP as an independent factor of economic development of the EU-28. The results of research indicate that EPS is significant factor of economic development of the EU countries.
\end{abstract}

Keywords: environmental policy stringency, environmental policy, export

JEL Classification: Q50, Q51

DOI: https://doi.org/10.31577/ekoncas.2021.05.04

\section{Introduction}

The theory and practice of the process of transition of the EU countries to green economy have dictated the need to clarify the essence and scientificpractical aspects of the formation and development of EP as a factor of economic

* Marta VOVK, Prydniprovska State Academy of Civil Engineering and Architecture, Faculty of Economics, Chernishevskogo 24a, 49600 Dnipro, Ukraine; e-mail: marta.brawin@ gmail.com

** Viktoriia VARENYK - Zoia PESTOVSKA - Petro ATAMAS, Alfred Nobel University, Department of Financial Analytics and International Audit, Sicheslavska Naberezhna St, 18, 49000 Dnipro, Ukrajina; e-mail: v.var@duan.edu.ua; at@duan.edu.ua; atamas40@duan.edu.ua

*** Oleksandr ATAMAS, Dnipro State Agrarian Economic University, Serhii Efremov St. 25, 49600 Dnipro, Ukraine; e-mail: atamas070174@gmail.com

**** Valentyna SHEVCHENKO, Alfred Nobel University, International Marketing Department, Sicheslavska Naberezhna 18, 49000 Dnipro, Ukraine; e-mail: shevchenkovn@ duan.edu.ua 
development of the country in today's new challenges of economic globalization. One of such challenges is the problem of transition from so-called brown economy to green economy while simultaneously maintaining economic development. About 40 years the EU Governments wonder whether harmonization of environment policy should be an additional condition for European integration.

An increase in the demand for natural resources forms the necessity of sustainable development. In such circumstances, the stringency of EP is rising due to the following reasons. Most EP efforts in the EU consist of implementing Directives that are developed by European Commission. Member states along with European Parliament have to approve the Directives. Under such circumstances, member states gain and lose their influence on decision-making process because they have to approve ER standards of other member states. Along with numerous Directives member states are obliged to comply with provisions of the EU emission trading system, Kyoto Protocol, REACH (Registration, Evaluation and Authorisation of Chemicals). Thus, achieving supranational and national goals related to pollution reduction means that for some the EU countries EPS could become an obstacle to keep harmful production and increase their incomes. Thus, the relevance of current paper lies in the necessity of identifying to what extent economic development of the EU-28 can be explained by the EPS. In current paper we introduce the indicator of EPS and statistically determine whether EP can be considered as an independent factor of economic development of the EU-28.

Current paper is structured as following. In the first section, we have conducted literature review on the perspectives of the effects of EP, the impact of EP on export of the countries, state of the art in the development of measures of EPS. The second section describes research design. The third section describes empirical results. The last section provides concluding remarks.

\section{Literature Review}

\subsection{Perspectives of the Effects of EP}

The influence of EP has been researched by the authors on the micro-, mesoand macro-level. The research on micro- and meso-level gives an opportunity to verify Porter hypothesis, pollution haven hypothesis and other theories and hypotheses aimed at identifying the influence of EP on the economic results, innovativeness of the firms and allocation/relocation of "dirty" production. In particular, Zhai Liu and Chan (2019) have researched the impact of environmental regulation on firm export in China and tested Porter and pollution haven 
hypotheses. The authors have outlined that the setting-up of the environmental standards under the Red Line policy boosts firm exports. The Red Line standard encourages companies to increase $R \& D$ expenditures and production efficiency. At the same time, the authors have also emphasized that the pollution haven hypothesis does not always apply in LDCs, that is, EP does not necessarily mean hurting firm exports. In case the government sets EP goals, like, for instance, holistic approach to EP, the companies enhance their production efficiency and innovation to stimulate exports. There are also research findings which support Porter hypothesis in the sense that EP enhances productivity and environmental quality (Ambec et al., 2013; Kriechel and Ziesemer, 2009; Petroni, Bigliardi and Galati, 2018; Přívara and Přívarová, 2019; Roy Chowdhury and Das, 2011; Sadeghzadeh, 2014; van Leeuwen and Mohnen, 2017).

Another theory, which links environment and economy, is so called "environmental Kuznets curve". It implies that economic development initially results in environmental degradation. After achieving a certain level of economic growth, it is suggested that the society improves the relationship with the environment and the levels of environmental degradation should be reduced (Ekins, 1997). However, it should be noted that there is no guarantee that economic growth will lead to environmental improvement. As reality shows, economic growth is often associated with more environmental inputs and higher emissions. Only targeted EP can bring improvements. Thus, it can be concluded that based on mentioned, Porter hypothesis more properly fits realities and serves a ground for sufficient coordination between economy and environment.

\subsubsection{The Experience of China}

Chinese policies represent interesting area research due to the fact that the country plays an important role in the world's economic development and environmental protection. Some industry level research findings identify positive influence of EP on industry transformation. In particular, the research of $\mathrm{Li}$ and Li (2019) was focused on empirical research on the intensity of environmental regulation and industrial green transformation in China. The authors have indicated that EP can effectively stimulate industrial green transformation by improving green total factor productivity. At the same time, literature findings also support pollution haven hypothesis (Guha, 2015; Martínez-Zarzoso, Vidovic and Voicu, 2017; Millimet and Roy, 2016; Rana and Sharma, 2019).

The research of Stavropoulos, Wall and Xu (2018) on environmental regulations and industrial competitiveness in China has shown that there is a U-shaped association between EP and industrial competitiveness, and not a simple linear relationship. The authors have concluded that only stringent EPs can create 
a positive effect on industrial competitiveness. Nevertheless, there may be a tradeoff at first, the government should not be too bothered. If EP is well designed, in the long-run its influence is positive. Thus, the government should set stringent EPs.

\subsubsection{EP Effects for the Advanced Economies}

The research conducted by Albrizio (2014) in a panel of OECD countries has shown that an increase in stringency of EP does not harm productivity growth or productivity levels - neither at the level of the entire economy nor at that of manufacturing industries. It has been also found out that at the industry level productivity growth was recorded resulting from a tightening in EPS for most technologically advanced countries. According to the research of the European Commission (2019) on the links between production, the environment and EP, in all cases, the positive macroeconomic impacts of EP are small and largely rely on the use of any tax revenues from market-based instruments.

The research of Gray (2015) at the firm level of USA has shown that the benefits to society from environmental regulation appear to be much larger than the costs of compliance. Neidell (2017) has concluded that in USA improvements in air quality have led to significant increases in worker productivity. Feng et al. (2019) have researched the impact of EPS on industrial productivity growth in OECD Countries. The results show that while stricter EP might shift a country's total cost in production upward, for countries, which have already adopted comparatively more stringent EP, further increasing their EPS enhances productivity in the long-run. More stringent EP renders the use of intermediate inputs more inelastic to the prices and decreases the substitutability between labour and intermediate inputs in the long-run. The authors conclude that more stringent EP would apply tighter control over the use of several intermediate inputs such as raw materials, energy and pollution-intensive services, leading to the use of these inputs being less sensitive to changes in their market prices. There is also evidence found by de Santis and Lasinio (2016) that the use of market based EP instruments contributes to innovations and productivity in the EU countries.

However, the results of research of Hille and Möbius (2019) on the effects of EP on innovation and productivity growth do not support the strong Porter Hypothesis. According to the authors, stricter EP fosters innovation and, therefore, has an indirect, yet not decisive, positive effect on productivity growth.

Dechezleprêtre and Sato (2014) have concluded based on extensive literature review of the impact of EP on productivity, production costs, employment, international relocation of polluting activities, innovation activity, firms competitiveness that these effects, however, appear to be small and temporary. In the 
longer run, the effects tend to be smaller than in the short run, implying that state policies such as labour markets regulations can contribute to diminishing or offsetting the temporary effects of environmental regulations on competitiveness. These effects seem more likely to happen within domestic boundaries where relocation barriers are low, than across borders. According to the research results, from international perspective, the estimated effects of EP on trade and investment location so far are negligible in comparison to other determinants, such quality of workers and market conditions.

However, other research findings, which come from country studies, encouraged us to conduct this research. In particular, among the papers, which show the influence of EP at the country level is present, is OECD research of the influence of EPS on productivity growth in OECD countries (Albrizio, 2014). There has been estimated "a reduced-form model of multi-factor productivity growth, where the effect of countries' environmental policies varies with pollution intensity of the industry and technological advancement". The results of the research have identified that at the aggregate economy level, a negative effect on productivity growth is one year ahead of the policy change. At the industry level, more stringent EP is associated with a short-term increase in industry-level productivity growth. At the firm level, only the technologically advanced firms are characterized by a positive effect on productivity growth from more stringent EP, whereas other firms, less productive ones, experience a productivity slowdown. In the section below we discuss in more detail the association between EP at the country level and country export which is considered as one of the most important factors of international competitiveness of the countries.

It can be summarized based on literature review that there is evidence of the positive impact of EP and, in particular, stringent EP in both the countries with advanced economies and China. Most often, as concluded by the authors, there is non-linear relationship between EPS and the effects on the economies. Moreover, the effect of stringent EP seems to be more visible in the long-run and in the short run the effects are more likely to be negative.

\subsection{The Impact of EP on Export of the Countries}

According to many studies country's exports plays a leading role in economic growth of the countries and their competitiveness (Falk, 2009; Lapatinas and Litina, 2019; Mahmoodi and Mahmoodi, 2016; Rusu and Roman, 2018; Sakyi et al., 2017; Schor, 2016; Sultanuzzaman et al., 2019; Zahonogo, 2016; Zhu and $\mathrm{Fu}, 2013)$. Furthermore, country's export is considered among globalization indicators. The extent to which a separate economy is involved in globalization process is crucial for nowadays reality as it shows how many advantages a country can 
obtain while participating in international economy. Thus, it is crucially important to identify whether country's exports is affected by its EP and in what a way.

As mentioned above, an increase in international fragmentation of production has strengthened fears that industrial activity may move to the locations/countries with less stringent EPs that, in fact, in line with the so-called pollution haven hypothesis. In case pollution haven hypothesis, the effects are strong, domestic responses to environmental challenges can demonstrate ineffective or meet strong resistance, however, there is not much evidence of this at the country level.

When researching how EP affect global value chains, Kozluk and Garsous (2016) have concluded that EP does not seem to be a major driver of international trade patterns, but have some significant effects on specialisation. More stringent domestic EP have no significant effect on overall trade in manufactured goods, but is related to a comparative disadvantage in "dirty" industries, and a corresponding advantage in "cleaner" industries. The effects are stronger for the domestic component of exports than for gross exports, yet especially smaller than the effects of trade liberalization. Another research for OECD countries (Arlinghaus, 2015) on the impacts of carbon prices on indicators of competitiveness, including exports has shown that there are positive effects of EP in the long-run.

Costantini and Mazzanti (2012) have found out that EP is not harmful for export competitiveness of the manufacturing sector, whereas specific energy tax policies and innovation efforts are positively associated with exports. EP and private innovation both trigger higher efficiency in the production process through various complementarity mechanisms, thus EP brings net benefits.

Babool and Reed (2010) have researched the impact of EPS on international competitiveness in manufacturing, in particular, on net exports, in OECD countries. The authors have found out positive association between net exports and EP for paper products, wood products and textile products, however, most manufacturing industries appeared to be harmed by more stringent EP.

Eisenbarth (2017) has researched whether the export tax equivalent of partial VAT reduction and export taxes are higher for products which are more pollution intensive along several dimensions. The research findings have indicated that the VAT reduction rates are set in a way that restraints exports of $\mathrm{SO}_{2}$ intensive and energy intensive products, water pollution intensive, from 2007 on.

De Santis (2012) has conducted the research aimed at estimating with the use of a proxi of environmental stringency, the effect of three major multilateral environmental agreements (MEAs) on 15 EU countries' bilateral exports. The results of the research support pollution haven theory and identify that the EU-15 bilateral export flows were positively affected by the presence of environmental agreements in the period 1988 - 2008. It was identified that MEAs membership 
in the sample period had an overall positive effect on the exports of EU-15. The average positive variations of exports (of EU-15 towards 24 OECD countries) induced by signing Kyoto, Montreal and UNFCCC agreements, could be partly explained by possible trade diversion effect in regards to the member states that did not sign MEAs and a related trade creation effect among environmental agreements members owing, for instance, to homogeneity of environmental-related production standards.

Ramzy and Zaki (2018) have researched the effect of EPS on agricultural trade between European Union and 20 MENA countries during the period $2001-2014$. The results have shown that EP affects agricultural trade between both regions because in the presence of excessive zero trade observations, they act as important fixed export costs that impact the trade probability. More stringent EPs enhance innovative efforts in cost-saving green technologies, which positively affect agricultural exports and increase productivity.

The research of Montagna, Pinto and Vlassis (2020) on the trade effects of international environmental agreements on the welfare of the countries has shown that introduction of the agreements can reduce the level of welfare in the non-participating countries due to the trade creation and trade diversion effects of the policy. Thus, the terms-of-trade effects of EP are substantial channel affecting the incentives of the countries to join an environmental agreement and can deteriorate the pollution haven effect. In the section below, we discuss current development of the measures of EPS.

\subsection{State of the Art in the Development of Measures of Environmental Policy Stringency}

In this section, we have provided the most significant and widely used measures of EPS in empirical studies. Since 1995, when firstly an index of EPS was presented by Dasgupta et al., many authors have tried to evaluate in an effective way the stringency of EP (Mody et al., 1995). This first index was constructed on the base of UN Environmental Program. Esty and Porter (2002) constructed Environmental Regulatory Regime Index based on the Environmental Sustainability Index and the Global Competitiveness Report 2001 - 2002 of WEF.

Organisation for Economic Co-operation and Development (OECD) has contributed a valuable insight to how EPS should be assessed and developed EPS Index (OECD, 2018). However, there is still no indicator available for every country. Other approaches to measuring EPS have been researched by Botta and Koźluk (2014) which are grouped by the authors into single policy change events, composite indicators of policies, surveys of perception, firm/plant level environment-related expenditures, shadow prices, environmental performance/outcomes. 


\section{Research Design}

\subsection{Hypothesis Development}

In our previous research on EP policy of the EU we have tested the hypothesis that the system of EP instruments applied in the developed EU countries is more diverse than in developing and transition economies due to the fact that developed countries have long established laws and formal governmental structures to address their environmental issues (Vovk, Dziura and Grešš, 2019). We have found out that the degree of variety of EP instruments among the EU members is dependent not only on the development of production and actual environmental problems, but also on other determinants of development, as in not all member states with a high number of production enterprises, the EP is diverse. Only in the United Kingdom, Denmark, Belgium, Netherlands Austria, Finland, France, Germany, Ireland, Luxembourg and Sweden the system of EP is the most diverse.

These countries joined the EU much earlier than many other member states, thus, they are characterized by a sounder institutional framework. With the use of cluster analysis method, we have identified the groups of the EU countries with similar competitive advantages and environmental performance. Cluster analysis has been conducted with the use of Ward method (1963). This method minimizes the sum of squares for any two (hypothetical) clusters, which can be formed at each step. This method intends to create small clusters. This property is also important for our research, since we have 28 countries, which are characterized by different levels of the development and competitiveness. Thus, the countries can be combined into classes (clusters) according to similar features. Then each cluster has been analyzed from the point of view of the practice of the use of different instruments of environmental policy.

The indicators for cluster analysis have been chosen in accordance with the three groups of factors of economic development of the countries: traditional factors of economic development of the countries, post-industrial factors of economic development and the factors of the resistance of the countries to external financial and economic shocks and crises. The dendogram of cluster analysis has been presented in the Figure 1. According to the Figure 1, we have obtained four clusters:

Cluster 1: Austria, Belgium, Denmark, Finland, France, Germany, Ireland, Luxembourg, Netherlands, Sweden and United Kingdom.

Cluster 2: Bulgaria, Croatia, Hungary, Romania and Slovakia.

Cluster 3: Cyprus, Czechia, Estonia, Latvia, Lithuania, Malta, Poland and Slovenia.

Cluster 4: Greece, Italy, Portugal and Spain. 
Figure 1

Dendrogram of Clusters

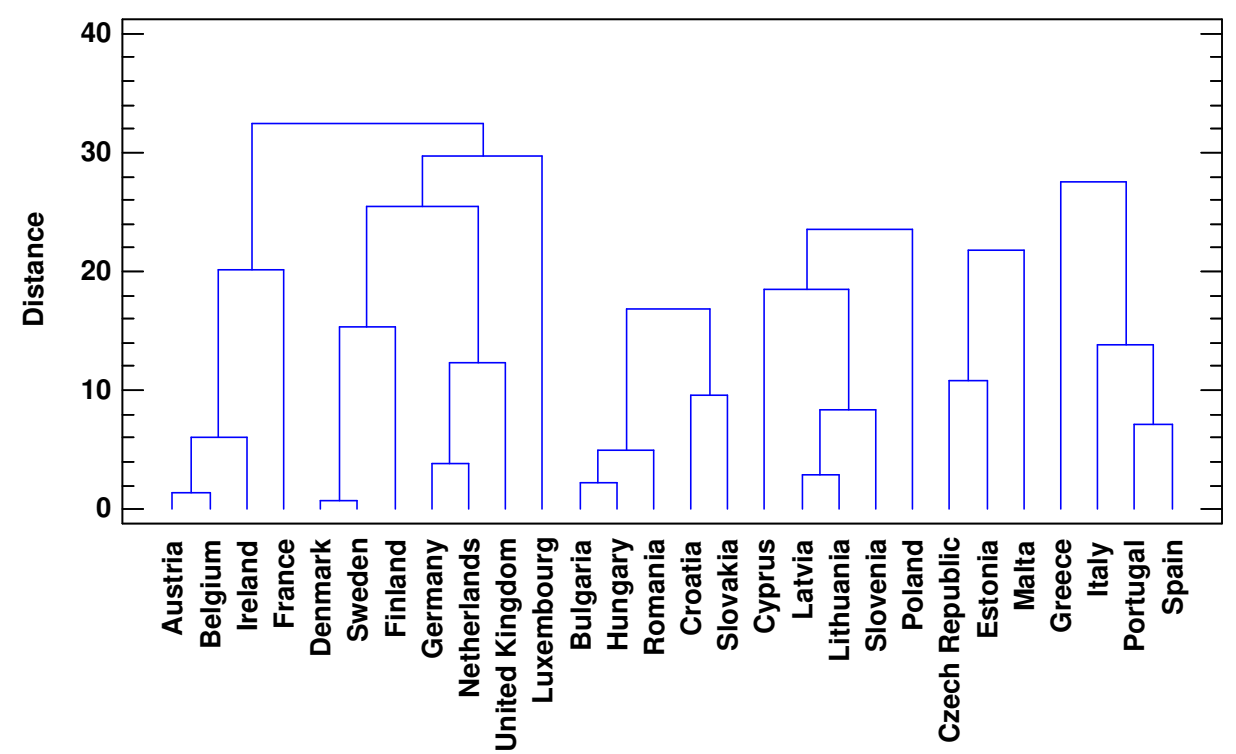

Source: Vovk, Dziura and Grešš (2019).

Our analysis of the practice of application of different EP instruments by EU countries (Table 1) has identified that the main EP instruments in the EU are subsidies, taxes and fees. It is noteworthy that the countries of the 1st cluster have the most diverse EP.

It could be explained by the higher production levels in these countries and the higher numbers of production firms, however, in fact, the real sector is mostly developed in the United Kingdom Spain, France, Italy, Germany and Poland and not all of these member states are in the 1st cluster (Vovk, Dziura and Grešš, 2019).

Thus, based on above mentioned results of our previous research, in current research we have tested the following hypothesis:

Hypothesis: there is causal effect between EPS and economic development of the EU-28

For testing our hypothesis, the following regression model has been employed:

$$
l_{\text {Export }}=\alpha_{0}+\alpha_{1} l_{G F C F}+\alpha_{2} \text { Upper }+\alpha_{3} l_{\mathrm{r} \& \mathrm{~d}}+\alpha_{4} l_{\text {EPS }}+\mu
$$

In the next section, we have described the data and method employed. 
Table 1

Application of EP Instruments in the EU

\begin{tabular}{|c|c|c|c|c|}
\hline Instruments & Cluster 1 & Cluster 2 & Cluster 3 & Cluster 4 \\
\hline & $\begin{array}{l}\text { Austria } \\
\text { Belgium } \\
\text { Denmark } \\
\text { Finland } \\
\text { France } \\
\text { Germany } \\
\text { Ireland } \\
\text { Luxembourg } \\
\text { Netherlands } \\
\text { Sweden } \\
\text { United Kingdom } \\
\end{array}$ & $\begin{array}{l}\text { Bulgaria } \\
\text { Croatia } \\
\text { Hungary } \\
\text { Romania } \\
\text { Slovakia }\end{array}$ & $\begin{array}{l}\text { Cyprus } \\
\text { Czech Republic } \\
\text { Estonia } \\
\text { Latvia } \\
\text { Lithuania } \\
\text { Malta } \\
\text { Poland } \\
\text { Slovenia }\end{array}$ & $\begin{array}{l}\text { Greece } \\
\text { Italy } \\
\text { Portugal } \\
\text { Spain }\end{array}$ \\
\hline $\begin{array}{l}\text { Subsidies (for example for } \\
\text { environmentally - friendly activities) }\end{array}$ & $\bullet$ & - & $\bullet$ & $\bullet$ \\
\hline $\begin{array}{l}\text { Taxes and fees (directly applied } \\
\text { to the pollution source, on input } \\
\text { or output of a production process }\end{array}$ & $\bullet$ & $\bullet$ & $\bullet$ & $\bullet$ \\
\hline $\begin{array}{l}\text { Low carbon policy tools: } \\
\text { Emission trading permits }\end{array}$ & $\bullet$ & Hungary only & $\begin{array}{l}\text { Czech Republic } \\
\text { Estonia } \\
\text { Latvia } \\
\text { Lithuania } \\
\text { Poland } \\
\text { Slovenia } \\
\end{array}$ & $\bullet$ \\
\hline Carbon taxes & $\begin{array}{l}\text { Denmark } \\
\text { Finland } \\
\text { France } \\
\text { Ireland } \\
\text { Sweden } \\
\text { United Kingdom }\end{array}$ & & $\begin{array}{l}\text { Estonia } \\
\text { Poland } \\
\text { Slovenia }\end{array}$ & $\begin{array}{l}\text { Portugal } \\
\text { Spain }\end{array}$ \\
\hline Environmental education & $\bullet$ & $\bullet$ & $\bullet$ & $\bullet$ \\
\hline Voluntary approaches & $\bullet$ & Slovakia only & $\begin{array}{l}\text { Czech Republic } \\
\text { Latvia }\end{array}$ & Italy only \\
\hline Deposit refund systems & $\begin{array}{l}\text { Denmark } \\
\text { Finland } \\
\text { Germany } \\
\text { Ireland } \\
\text { Luxembourg } \\
\text { Netherlands } \\
\text { Sweden } \\
\text { United Kingdom }\end{array}$ & $\bullet$ & $\bullet$ & $\begin{array}{l}\text { Italy } \\
\text { Spain }\end{array}$ \\
\hline National strategies & $\bullet$ & $\bullet$ & $\bullet$ & $\bullet$ \\
\hline Regulatory instruments & $\bullet$ & - & $\bullet$ & $\bullet$ \\
\hline
\end{tabular}

Source: Based on the data from OECD (2018); European Environment Agency (2016).

\subsection{Data and Method}

\subsubsection{Indicator for Assessing EPS}

Given there is no widely established indicator for EPS, in current paper we have proposed to apply the approach based on indirect assessing the pollution abatement costs and characterized by a simple way of calculation. As an environmental parameter, we propose to use the following indicator:

$$
e_{i s}=\frac{E_{i s}}{V_{i s}}
$$


where

$e_{i s} \quad-$ indicator of EPS in industry $i$, sector $s$,

$E_{i s}$ and $V_{i s}$-emissions level and value added of the industry $i$ in sector $s$ respectively.

The higher the value of indicator (2), the less strict in certain industry EPS is. Thus, taking into account the proposed method for calculating EPS, we expect negative correlation between EPS and economic growth of the EU-28. The use of this indicator gives an opportunity to calculate EPS for different sectors as well as for the whole country level. The data for calculating this indicator are available on the Eurostat Website or World Input-Output Database.

In current research, we have used the data from Eurostat for emissions of $\mathrm{CO}_{2}$, tonne for NACE activities and gross value added for NACE activities, at current prices, million units of national currency. We have used the emissions of carbon dioxide given the fact that there is considerable emission of this gas from energy and environmental sectors. We emphasize that it is important to use $\mathrm{CO}_{2}$ emissions accounts due to the fact that $\mathrm{CO}_{2}$ emissions account for around $80 \%$ of all greenhouse gas emissions from the manufacturing processes. UNECE accounts currently include different variations of this indicator. In particular, there is introduced indicator on $\mathrm{CO}_{2}$ emissions from manufacturing (in $\mathrm{kg}$ )-to-manufacturing value added and $\mathrm{CO}_{2}$ emissions form fuel combustion-to-value added of economic activities (Nagy, 2019). Other authors have also used other variations of this indicator. In particular, Randers (2012) has used greenhouse gas emissions per unit of value added ("GEVA"). Carbon dioxide emissions have been also used for similar indicator by European Environment Agency (2013), Liu, Lackner and Fan (2021).

The usefulness of this indicator is that it represents changes in the average carbon intensity of the energy mix, in the structure of the manufacturing sector, in the energy efficiency of production in different sectors. Currently, all the EU countries in more or less extent are suffering from $\mathrm{CO}_{2}$ pollution. Taking into account that value added is constantly growing in all the EU-28, the value of proposed EPS indicator can be decreased or increased mainly due to the changing level of emissions. Thus, such a method of EPS calculation can provide real information on EPS level among the EU-28 in a sufficient way. In the next section, we have presented research design of current study

\subsubsection{Regression Analysis}

Regression analysis has been conducted for four clusters of the EU member states described above with the use of European Commission data. For all indicators there has been used available data from 1995 to 2016. For conducting regression analysis, we have used panel data and fixed effects estimation. Since our regression 
analysis contains panel data, for diagnostics of the models' goodness of fit we have used joint test on named regressors and test for differing group intercepts as the basis for analysis of panel data, which in an effective way show the overall quality of the models, given not large number of observations and panel data structure. In the Table 2 below, the description of variables has been presented.

T a ble 2

Description of Variables

\begin{tabular}{|c|c|c|c|}
\hline Variable & Description & Source & $\begin{array}{c}\text { Expected sign } \\
\text { of the influence } \\
\text { on emigration flow }\end{array}$ \\
\hline $\begin{array}{l}\text { 1_Export: } \\
\text { dependent variable }\end{array}$ & $\begin{array}{l}\text { Logarithm of the value of exports of goods } \\
\text { and services, at current prices in million EUR }\end{array}$ & $\begin{array}{l}\text { European } \\
\text { Commssion } \\
(2018 \mathrm{a})\end{array}$ & \\
\hline 1_GFCF & $\begin{array}{l}\text { Logarithm of the value of gross fixed capital } \\
\text { formation at current prices, million EUR }\end{array}$ & $\begin{array}{l}\text { European } \\
\text { Commssion } \\
(2016)\end{array}$ & + \\
\hline Upper & $\begin{array}{l}\text { Upper secondary and post-secondary } \\
\text { non-tertiary education (levels } 3 \text { and } 4 \text { ), } \\
\text { percentage of total employment }\end{array}$ & $\begin{array}{l}\text { European } \\
\text { Commssion } \\
(2018 b)\end{array}$ & + \\
\hline 1_R\&D & $\begin{array}{l}\text { Logarithm of the value of gross domestic } \\
\text { expenditure on research and development } \\
\text { (R\&D), million units of national currency }\end{array}$ & $\begin{array}{l}\text { European } \\
\text { Commssion } \\
(2018 \mathrm{c}) \\
\end{array}$ & + \\
\hline 1_EPS & Logarithm of the indicator of EPS & $\begin{array}{l}\text { European } \\
\text { Commssion } \\
(2016 ; 2017) \\
\end{array}$ & - \\
\hline
\end{tabular}

Source: Authors.

An indicator of exports of goods and services has been used for our analysis, since according to many studies it plays a leading role in economic growth of the countries. Furthermore, as we already have identified, exports of the country is an indicator, which is imposed by EP. Our choice is also explained by the importance of the analysis of globalization indicators. The extent to which a separate economy is involved in globalization process is crucial for nowadays reality as it shows how many advantages a country can obtain while participating in international economy. It should be noted that according to United Nations Economic Commission for Europe indicators of globalization include the following ones ("Globalization indicators by Country, Indicator and Year," 2018):

- total exports to GDP, \%;

- total trade to GDP, \%;

- domestic final demand met by total imports, \%;

- trade balance in US dollars;

- trade balance to GDP, \%;

- trade balance to total trade, \%;

- total trade per capita;

- export performance, $\%$; 
- export performance, in US dollars;

- import coverage by exports, \%;

- growth rate of total trade, $\%$

Thus, from this list could be seen that international trade plays the most important role in globalization process that is why the amount of exports is perceived as an important indicator of economic development of the countries.

The rationale for the use other variables as factors of export competiveness is based on the literature findings which indicate positive association between them and exports (Jermsittiparsert et al., 2019; Rani and Kumar, 2019; Petkova et al., 2020; Pilinkienè, 2015; Feldmann et al., 2019; Dong et al., 2020; Toppinen et al., 2019; Stevans et al., 2012; Kharlamova and Vertelieva, 2013).

\section{Empirical Results}

In the Table 3 the regression analysis results have been presented. The Table 4 contains the results of joint test on named regressors and test for differing group intercepts.

T a b le 3

Regression Results: Fixed Effects

\begin{tabular}{|l|c|c|c|c|}
\hline Variables & Cluster 1 & Cluster 2 & Cluster 3 & Cluster 4 \\
\hline \multicolumn{5}{|c|}{ Dependent variable: l_Export } \\
\hline Constant & $5.23^{* * *}$ & $11.22^{* * *}$ & $9.35^{* * *}$ & $18.24 * * *$ \\
& $(1.93)$ & $(1.8)$ & $(1)$ & $(2.8)$ \\
1_GFCF & $0.42^{* * *}$ & 0.12 & $0.13^{* *}$ & -0.11 \\
& $(0.09)$ & $(0.14)$ & $(0.06)$ & $(0.07)$ \\
1_R\&D & $0.42^{* * *}$ & $0.2^{*}$ & $0.42^{* * *}$ & $-0.38^{*}$ \\
& $(0.12)$ & $(0.1)$ & $(0.06)$ & $(0.22)$ \\
1_EPS & $-0.29 * * *$ & $-0.71^{* * *}$ & $-0.24 * *$ & $-0.42^{*}$ \\
& $(0.1)$ & $(0.18)$ & $(0.09)$ & $(0.21)$ \\
Upper & -0.00 & -0.00 & -0.03 & $0.01^{*}$ \\
& $(0.00)$ & $(0.01)$ & $(0.00) * * *$ & $(0.00)$ \\
Observations & 92 & 45 & 72 & 36 \\
Number of countries & 11 & 5 & 8 & 4 \\
LSDV R-squared & 0.99 & 0.97 & 0.99 & 0.99 \\
Within R-squared & 0.72 & 0.72 & 0.78 & 0.53 \\
\hline
\end{tabular}

Note: Standard errors in parentheses. * $\mathrm{p}<0.10 ; * * \mathrm{p}<0.05 ; * * * \mathrm{p}<0.01$.

Source: Authors' calculations.

T a b l e 4

Joint Test on Named Regressors and Test for Differing Group Intercepts

\begin{tabular}{|l|c|c|c|c|}
\hline Tests/Models & Cluster 1 & Cluster 2 & Cluster 3 & Cluster 4 \\
\hline Joint test on named regressors & 51.08 & 23.93 & 54.55 & 7.93 \\
& $(0.00)$ & $(0.00)$ & $(0.00)$ & $(0.00)$ \\
\hline Test for differing group intercepts & 126.18 & 52.97 & 41.68 & 26.29 \\
& $(0.00)$ & $(0.00)$ & $(0.00)$ & $(0.00)$ \\
\hline
\end{tabular}

Note: p-values are in parentheses.

Source: Authors' statistical results. 
The results of regression analysis have shown that in all clusters EPS is significant factor that has positive impact on exports of goods and services in the countries. In our case, the negative coefficients of EPS mean that the less ratio of emissions of carbon dioxide to value added in all NACE activities, the more stringent EP is in the country. In other words, the less the value of indicator EPS, the higher value of exports of goods and services in the country is observed.

In the fourth cluster the significance of EPS is the lowest. This could be explained by existing financial instability in PIGS countries, which is significant obstacle to implement effective environmental policy.

\section{Conclusion}

In current research, we have proposed indicator for assessing EPS in the EU-28 countries and approach for analyzing the relationship between economic development of the region and EPS along with the main factors of economic development of the countries. We have tested the hypothesis that there is causal effect between EPS and economic development of the EU-28. It has been found out that in all countries EPS is significant factor, which is negatively associated with exports meaning that the less ratio of emissions of carbon dioxide to value added, the more stringent EP is in the country.

There are many concerns about current environmental problems in the EU-28. The convergence process in the EU was mainly focused on economical aspects. But after many years of extensive use of natural resources the governments faced with variety environmental problems. Our previous and current research has shown that among the EU countries there are considerable differences both in economic and environmental development. Such countries, as, for instance, Germany, Austria, Belgium, France, Denmark, United Kingdom, France and which joined the EU earlier than other countries, are characterized by higher economic development and advanced system of EP. Such countries, as Slovakia, Poland, Slovenia, Hungary, and Estonia are still lagging behind above mentioned countries not only in terms of economic development indicators but also environmental performance.

For achieving more sufficient and environmental-agreed economic development, environmental performance indicators should be also included in the system of integration and convergent policies of the EU (Vovk, 2020). It should be noted that the idea of integration of environmental policy in convergent policies of the EU should become an imperative for the EU applicants and candidates as achieving high economic development indicators, inconsistent with environmental issues of the country, is meaningless as international experience shows. 


\section{References}

ALBRIZIO, S. (2014): Empirical Evidence on the Effects of Environmental Policy Stringency on Productivity Growth. [OECD Economics Department Working Papers.] [Online.] Paris: OECD. Available at: $\langle$ https://www.oecd-ilibrary.org/economics/empirical-evidence-on-the-effects-of-environmental-policy-stringency-on-productivity-growth_5jxrjnb36b40-en>. [Accessed 9 February 2021.]

AMBEC, S. - COHEN, M. A. - ElGIE, S. - LANOIE, P. (2013): The Porter Hypothesis at 20: Can Environmental Regulation Enhance Innovation and Competitiveness? Review of Environmental Economics and Policy, 7, No. 1, pp. 2 - 22. DOI: 10.1093/reep/res016.

ARLINGHAUS, J. (2015): Impacts of Carbon Prices on Indicators of Competitiveness: A Review of Empirical Findings. [OECD Environment Working Papers.] [Online.] Paris: OECD. Available at: <https://www.oecd-ilibrary.org/environment/impacts-of-carbon-prices-on-indicators-ofcompetitiveness_5js37p21grzq-en>. [Accessed 10 February 2021.]

BABOOL, A. - REED, M. (2010): The Impact of Environmental Policy on International Competitiveness in Manufacturing. Applied Economics, 42, No. 18, pp. 2317 - 2326. DOI: $10.1080 / 00036840701858026$.

BOTTA, E. - KOŹLUK, T. (2014): Measuring Environmental Policy Stringency in OECD Countries. [OECD Economics Department Working Papers.] [Online.] Paris: OECD. Available at: <http://www.oecd-ilibrary.org/economics/measuring-environmental-policy-stringency-inoecd-countries_5jxrjnc45gvg-en>. [Accessed 14 January 2018.]

COSTANTINI, V. - MAZZANTI, M. (2012): On the Green and Innovative Side of Trade Competitiveness? The Impact of Environmental Policies and Innovation on EU Exports. Research Policy, 41, No. 1, pp. 132 - 153. DOI: 10.1016/j.respol.2011.08.004.

DE SANTIS, R. - JONA LASINIO, C. (2016): Environmental Policies, Innovation and Productivity in the EU. Global Economy Journal, 16, No. 4, pp. 615 - 635. DOI: 10.1515/gej-2015-0060.

DE SANTIS, R. (2012): Impact of Environmental Regulations on Trade in the Main EU Countries: Conflict or Synergy?: Impact of Environmental Regulations on Trade. The World Economy, 35, No. 7, pp. 799 - 815. DOI: 10.1111/j.1467-9701.2012.01450.x.

DECHEZLEPRÊTRE, A. - SATO, M. (2014): The Impacts of Environmental Regulations on Competitiveness. [Online.] London: Grantham Research Institute for Cliamte Change and the Environment Policy Brief. DOI: 10.13140/RG.2.1.2279.1204. Available at: <http://rgdoi.net/10.13140/RG.2.1.2279.1204>. [Accessed 17 February 2020.]

DONG, N. T. - DIEM, T. T. A. - CHINH, B. T. H. - HIEN, N. T. D. (2020): The Interaction between Labor Productivity and Competitiveness in Vietnam. The Journal of Asian Finance, Economics, and Business, 7, No. 11, pp. 619 - 627. DOI: 10.13106/JAFEB.2020.VOL7.NO11.619.

EISENBARTH, S. (2017): Is Chinese Trade Policy Motivated By Environmental Concerns? Journal of Environmental Economics and Management, 82, pp. 74 - 103. DOI: 10.1016/j.jeem.2016.10.001.

EKINS, P. (1997): The Kuznets Curve for the Environment and Economic Growth: Examining the Evidence. Environment and Planning A: Economy and Space, 29, No. 5, pp. 805 - 830. DOI: $10.1068 / \mathrm{a} 290805$.

ESTY, D. - PORTER, M. E. (2002): Ranking National Environmental Regulation and Performance: A Leading Indicator of Future Competitiveness? [The Global Competitiveness Report 2001 - 2002.] [Online.] New York: Oxford University Press. Available at: <http://www.hbs.edu/faculty/Publication \% 20Files/GCR_20012002_Environment_5d282a24-bb10-4a9a-88bd-6ee05e8c6678.pdf>.

EUROPEAN COMMISSION. DIRECTORATE GENERAL FOR ENVIRONMENT, CAMBRIDGE ECONOMETRICS, IEEP and DENKSTATT (2019): Links between Production, the Environment and Environmental Policy. [Online.] LU: Publications Office. Available at: <https://data.europa.eu/doi/10.2779/569064>. [Accessed 9 February 2021.]

EUROPEAN COMMISSION (2016): Value Added by NACE Rev. 2. [Online.] Eurostat. Available at: <http://ec.europa.eu/eurostat/tgm/table.do?tab=table\&init=1\&plugin=1\&pcode $=$ tin $00150 \&$ language $=\mathrm{en}>$. 
EUROPEAN COMMISSION (2017): Air Emissions Accounts by NACE Rev. 2 Activity. [Online.] Eurostat. Available at: <http://appsso.eurostat.ec.europa.eu/nui/show.do?dataset=env_ac_ainah_r2\&lang=en>.

EUROPEAN COMMISSION (2018a): Exports of Goods and Services, at Current Prices in Million EUR. [Online.] Eurostat. Available at: 〈http://ec.europa.eu/eurostat/tgm/table.do?tab=table\& init $=1 \&$ plugin $=1 \&$ language $=$ en $\&$ pcode $=$ tec $00110>$.

EUROPEAN COMMISSION (2018b): Employment by Educational Attainment Level - Annual Data. [Online.] Eurostat. Available at: <http://appsso.eurostat.ec.europa.eu/nui/show.do?dataset=lfsi_educ_a\&lang=en>.

EUROPEAN COMMISSION (2018c): Gross Domestic Expenditure on Research and Development (R\&D). [Online.] Eurostat. Available at: $\langle$ http://ec.europa.eu/eurostat/tgm/table.do?tab= table\&init $=1 \&$ plugin $=1 \&$ language $=$ en $\&$ pcode $=$ tipsst $10>$.

EUROPEAN ENVIRONMENT AGENCY (2013): European Union $\mathrm{CO}_{2}$ Emissions: Different Accounting Perspectives. [Online.] LU: Publications Office. Available at: <https://data.europa.eu/doi/10.2800/10691>. [Accessed 8 February 2021.]

EUROPEAN ENVIRONMENT AGENCY (2016): Current Environmental Policy. European Environment Agency. [Online.] Available at: <https://www.eea.europa.eu/publications/92-827-40838/page004.html>.

FALK, M. (2009): High-tech Exports and Economic Growth in Industrialized Countries. Applied Economics Letters, 16, No. 10, pp. 1025 - 1028. DOI: 10.1080/13504850701222228.

FELDMANN, P. - JACOMOSSI, R. - BARRICHELLO, A. - MORANO, R. (2019): The Relationship between Innovation and Global Competitiveness: The Mediating Role of Management Practices Evaluated by Structural Equation Modeling. Review of Business Management, 21, No. 2, pp. 195 - 212. DOI: 10.7819/rbgn.v21i2.3970.

FENG, G. - MCLAREN, K. - YANG, O. - ZHANG, X. - ZHAO, X. (2019): The Impact of Environmental Policy Stringency on Industrial Productivity Growth: A Semi-Parametric Study of OECD Countries. [Online.] SSRN Electronic Journal. DOI: 10.2139/ssrn.3492795. Available at: 〈https://www.ssrn.com/abstract=3492795>. [Accessed 9 February 2021.]

GRAY, W. (2015): Environmental Regulations and Business Decisions. [Online.] Bonn: IZA World of Labor. DOI: 10.15185/izawol.187. Available at: <http://wol.iza.org/articles/environmentalregulations-and-business-decisions $>$. [Accessed 9 February 2021.]

GUHA, S. (2015): Pollution Haven Hypothesis - A Meta-analysis. Arthaniti-Journal of Economic Theory and Practice, 14, No. 1 - 2, pp. 70 - 96. DOI: 10.1177/0976747920150103.

HILLE, E. - MÖBIUS, P. (2019): Environmental Policy, Innovation, and Productivity Growth: Controlling the Effects of Regulation and Endogeneity. Environmental and Resource Economics. 73, No. 4, pp. 1315 - 1355. DOI: 10.1007/s10640-018-0300-6.

JERMSITTIPARSERT, K. - SAENGCHAI, S. - BOONRATTANAKITTIBHUMI, C. - CHANKOSON, T. (2019): The Impact of the Government Expenditures, Gross Capital Formation, Trade, and Portfolio Investment on the Economic Growth of Asean Economies. Journal of Security and Sustainability Issues, December, pp. 571 - 584. DOI: 10.9770/jssi.2019.9.2(16).

KHARLAMOVA, G. - VERTELIEVA, O. (2013): The International Competitiveness of Countries: Economic-Mathematical Approach. Economics \& Sociology, 6, No. 2, pp. 39 - 52. DOI: 10.14254/2071-789X.2013/6-2/4.

KRIECHEL, B. - ZIESEMER, T. (2009): The Environmental Porter Hypothesis: Theory, Evidence, and a Model of Timing of Adoption. Economics of Innovation and New Technology, 18, No. 3, pp. 267 - 294. DOI: 10.1080/10438590801943235.

KOZLUK, T. - GARSOUS, G. (2016): How Stringent Are Environmental Policies? Policy Perspectives. [A Review of OECD Work on Indicators of Environmental Policy Stringency (EPS).] [Online.] Paris: OECD. Available at: <https://www.oecd.org/eco/greeneco/How-stringent-areenvironmental-policies.pdf $>$. [Accessed 25 October 2017.]

LAPATINAS, A. - LITINA, A. (2019): Intelligence and Economic Sophistication. Empirical Economics, 57, No. 5, pp. 1731 - 1750. DOI: 10.1007/s00181-018-1511-y. 
LI, H. - LI, B. (2019): The Threshold Effect of Environmental Regulation on the Green Transition of the Industrial Economy in China. Economic Research-Ekonomska Istraživanja, 32, No. 1, pp. 3134 - 3149. DOI: 10.1080/1331677X.2019.1661001.

LIU, H. - LACKNER, K. - FAN, X. (2021): Value-added Involved in CO Emissions Embodied in Global Demand-supply Chains. Journal of Environmental Planning and Management, 64, No. 1, pp. 76 - 100. DOI: 10.1080/09640568.2020.1750352.

MAHMOODI, M. - MAHMOODI, E. (2016): Foreign Direct Investment, Exports and Economic Growth: Evidence from Two Panels of Developing Countries. Economic Research-Ekonomska Istraživanja, 29, No. 1, pp. 938 - 949. DOI: 10.1080/1331677X.2016.1164922.

MARTÍNEZ-ZARZOSO, I. - VIDOVIC, M. - VOICU, A. M. (2017): Are the Central East European Countries Pollution Havens? The Journal of Environment \& Development, 26, No. 1, pp. 25 - 50. DOI: 10.1177/1070496516670196.

MILLIMET, D. L. - ROY, J. (2016): Empirical Tests of the Pollution Haven Hypothesis When Environmental Regulation is Endogenous: Empirical Tests of the Pollution Haven Hypothesis. Journal of Applied Econometrics, 31, No. 4, pp. 652 - 677. DOI: 10.1002/jae.2451.

MODY, A. - ROY, S. - WHEELER, D. - DASGUPTA, S. (1995): WPS1448: Environmental Regulation and Development : A Cross-country Empirical Analysis. [Policy Research Working Paper.] [Online.] Washington, DC: World Bank. Available at: $<$ http://documents.worldbank.org/curated/en/722831468740697649/Environmental-regulationand-development-a-cross-country-empirical-analysis>.

MONTAGNA, C. - PINTO, A. N. - VLASSIS, N. (2020): Welfare and Trade Effects of International Environmental Agreements. Environmental and Resource Economics, 76, No. 2 - 3, pp. 331 - 345. DOI: 10.1007/s10640-020-00428-x.

NAGY, M. (2019): SDG Indicator 9.4.1. CO2 Emissions per Unit of Value Added. [Online.] Moscow, Russian Federation: UNECE. Available at: <https://unece.org/fileadmin/DAM/stats/documents/ ece/ces/ge.33/2019/mtg2/S2_2_Ind_9_4_1_CO2_EN.pdf >. [Accessed 8 February 2021.]

NEIDELL, M. (2017): Air Pollution and Worker Productivity. [Online.] IZA World of Labor. DOI: 10.15185/izawol.363. Available at: <https://wol.iza.org/articles/air-pollution-and-workerproductivity/long>. [Accessed 9 February 2021.]

OECD (2016): Do Environmental Policies Affect Global Value Chains?: A New Perspective on the Pollution Haven Hypothesis. [Economics Department Working Papers.] [Online.] Paris: OECD. Available at: <https://www.oecd-ilibrary.org/economics/do-envi-ron-mental-policiesaffect-global-value-chains_5jm2hh7nf3wd-en>. [Accessed 9 March 2020.]

OECD (2018): Environmental Policy Stringency Index. [Online.] Paris: OECD. Available at: <https://stats.oecd.org/Index.aspx?DataSetCode=EPS >.

PETKOVA, L. - BEREZINA, O. - HONCHARENKO, I. - BEREZHNA, L. - MARUSHCHAK, D. (2020): Management of the National Economy Productivity: The Experience of European Integration. E3S Web of Conferences, 166, pp. 13014. DOI 10.1051/e3sconf/202016613014.

PETRONI, G. - BIGLIARDI, B. - GALATI, F. (2018): Rethinking the Porter Hypothesis: The Underappreciated Importance of Value Appropriation and Pollution Intensity. Review of Policy Research, December, pp. e0001. DOI: 10.1111/ropr.12317.

PILINKIENĖ, V. (2015): R\&D Investment and Competitiveness in the Baltic States. Procedia Social and Behavioral Sciences, 213, pp. 154 - 160. DOI: 10.1016/j.sbspro.2015.11.419.

PŘíVARA, A. - PŘíVAROVÁ, M. (2019): Nexus between Climate Change, Displacement and Conflict: Afghanistan Case. Sustainability, 11, No. 20, pp. 5586. DOI: 10.3390/su11205586.

RAMZY, M. - ZAKI, C. (2018): Do Environment Regulations Matter for EU-MENA Trade? Applied Economics, 50, No. 39, pp. 4197 - 4221. DOI: 10.1080/00036846.2018.1441519.

RANA, R. - SHARMA, M. (2019): Dynamic Causality Testing for EKC Hypothesis, Pollution Haven Hypothesis and International Trade in India. The Journal of International Trade \& Economic Development, 28, No. 3, pp. 348 - 364. DOI: 10.1080/09638199.2018.1542451.

RANDERS, J. (2012): Greenhouse Gas Emissions per Unit of Value Added ("GEVA"). A Corporate Guide to Voluntary Climate Action. Energy Policy, 48, pp. 46 - 55. DOI: 10.1016/j.enpol.2012.04.041. 
RANI, R. - KUMAR, N. (2019): On the Causal Dynamics between Economic Growth, Trade Openness and Gross Capital Formation: Evidence from BRICS Countries. Global Business Review, 20, No. 3, pp. 795 - 812. DOI: 10.1177/0972150919837079.

ROY CHOWDHURY, I. - DAS, S. K. (2011): Environmental Regulation, Green R\&D and the Porter Hypothesis. Indian Growth and Development Review, 4, No. 2, pp. 142 - 152. DOI: $10.1108 / 17538251111172041$.

RUSU, V. D. - ROMAN, A. (2018): An Empirical Analysis of Factors Affecting Competitiveness of C.E.E. Countries. Economic Research-Ekonomska Istraživanja, 31, No. 1, pp. $2044-2059$. DOI: $10.1080 / 1331677 X .2018 .1480969$.

SADEGHZADEH, J. (2014): The Impact of Environmental Policies on Productivity and Market Competition. Environment and Development Economics, 19, No. 5, pp. 548 - 565. DOI: $10.1017 / \mathrm{S} 1355770 \mathrm{X} 14000035$.

SAKYI, D. - VILLAVERDE, J. - MAZA, A. - BONUEDI, I. (2017): The Effects of Trade and Trade Facilitation on Economic Growth in Africa: Trade and Trade Facilitation. African Development Review, 29, No. 2, pp. 350 - 361. DOI: 10.1111/1467-8268.12261.

SCHOR, A. (2016): Is Trade Good For Development? The Elusive Question. [Online.] Brazilian Political Science Review, 10, No. 2, pp. 1 - 21. DOI: 10.1590/1981-38212016000200008. Available at: <http://www.scielo.br/scielo.php?script=sci_arttext\&pid=S1981-38212016000200205\&lng =en\&tlng=en>. [Accessed 10 March 2020.]

STAVROPOULOS, S. - WALL, R. - XU, Y. (2018): Environmental Regulations and Industrial Competitiveness: Evidence from China. Applied Economics, 50, No. 12, pp. 1378 - 1394. DOI: 10.1080/00036846.2017.1363858.

STEVANS, L. K. - NEELANKAVIL, J. P. - MENDOZA, R. - SHANKAR, S. (2012): The Economic Competitiveness of Countries: A Principal Factors Approach. International Journal of Economics and Finance, 4, No. 12, pp. p76. DOI: 10.5539/ijef.v4n12p76.

SULTANUZZAMAN, Md R. - FAN, H. - MOHAMUED, E. A. - HOSSAIN, Md I. - ISLAM, M. A. (2019): Effects of Export and Technology on Economic Growth: Selected Emerging Asian Economies. Economic Research-Ekonomska Istraživanja, 32, No. 1, pp. 2515 - 2531. DOI: 10.1080/1331677X.2019.1650656.

TOPPINEN, A. - SAURU, M. - PÄTÄRI, S. - LÄHTINEN, K. - TUPPURA, A. (2019): Internal and External Factors of Competitiveness Shaping the Future of Wooden Multistory Construction in Finland and Sweden. Construction Management and Economics, 37, No. 4, pp. $201-216$. DOI: $10.1080 / 01446193.2018 .1513162$.

VAN LEEUWEN, G. - MOHNEN, P. (2017): Revisiting the Porter Hypothesis: An Empirical Analysis of Green Innovation for the Netherlands. Economics of Innovation and New Technology, 26, No. 1 - 2, pp. 63 - 77. DOI: 10.1080/10438599.2016.1202521.

VOVK, M. (2020): Public Investments as a Factor of Regional Integration of the EU. Journal of Modern Economic Research, 2, No. 1, pp. 41 - 53.

VOVK, M. - DZIURA, B. - GREŠŠ, M. (2019): Environmental Policy of the EU: Insights for Further Development. [Online.] Geografický časopis - Geographical Journal, 71, No. 1, pp. 15 - 38. DOI: 10.31577/geogrcas.2019.71.1.02. Available at: <https://www.sav.sk/index.php?lang=sk\&doc =journal-list\&part=article_response_page\&journal_article_no=16775>. [Accessed 13 March 2020.]

WARD, J. H. (1963): Hierarchical Grouping to Optimize an Objective Function. Journal of the American Statistical Association, 58, No. 301, pp. 236 - 244. DOI: $10.1080 / 01621459.1963 .10500845$.

ZAHONOGO, P. (2016): Trade and Economic Growth in Developing Countries: Evidence from Sub-Saharan Africa. Journal of African Trade, 3, No. 1 - 2, pp. 41 - 56. DOI: 10.1016/j.joat.2017.02.001.

ZHAI, H. - LIU, D. - CHAN, K. C. (2019): The Impact of Environmental Regulation on Firm Export: Evidence from China's Ecological Protection Red Line Policy? Sustainability, 11, No. 19, pp. 5493. DOI: 10.3390/su11195493.

ZHU, S. - FU, X. (2013): Drivers of Export Upgrading. World Development, 51, pp. 221 - 233. DOI: 10.1016/j.worlddev.2013.05.017. 